\title{
THE PREVALENCE OF CIGARETTE-SMOKING AMONG MALE INTERMEDIATE SCHOOL STUDENTS IN JEDDAH, SAUDI ARABIA- A CROSS-SECTIONAL STUDY
}

\author{
Ahmad H. Almehmadi*
}

\begin{abstract}
Objective: The aim of this study was to observe the prevalence rate of cigarette smoking among intermediate students in different school types in Saudi Arabia. The effectiveness of an awareness program towards smoking cessation that was administered in this study was also evaluated.

Materials and Methods: This cross-sectional study was conducted among 13-15-year-old male intermediate school students $(n=435)$ in Saudi Arabia in three different school types (government, private, international). The Global Youth Tobacco Survey core questionnaire were given to assess the students' tobacco-use along with their demographic information. A clinical examination was performed by calibrated examiners for plaque, gingivitis, caries, and mucosal lesions. An awareness program on smoking cessation was conducted to these students.
\end{abstract}

Results: It was observed that $30.1 \%$ of the students had tried cigarette smoking, of which about $4.3 \%$ smoked more than 20 cigarettes/day. The majority of the students $(87 \%)$ had an intent towards smoking cessation, and about $80 \%$ of them did not feel compelled because of peer pressure. Also, about $74.3 \%$ of the students were not aware of any means to quit smoking and $57.9 \%$ of the students had watched media content on tobacco-use.

Conclusion: The study concluded that tobacco-use was prevalent among male intermediate school students with a majority of them intending to or have tried to quit the habit. Peer pressure may not have resulted in development of the habit but about half of the population has viewed media content with tobacco-use. Awareness programs on implications of smoking and cessation is warranted at school-level.

KEY WORDS: Prevalence; Smoking; Intermediate Students; Awareness; Smoking cessation.

* Assistant Professor and Consultant in Periodontics, Department of Oral Biology, Faculty of Dentistry, King Abdulaziz University, Jeddah, Saudi Arabia 


\section{INTRODUCTION}

Tobacco epidemic is affecting the whole world. By 2025, the numbers of smokers are expected to increase from 1.1 to 1.6 billion adults (Bala et al. 2013), (The W 1999). The use of tobacco products represents the major cause of preventable illness and death in the developed world. It killed about 100 million in the $20^{\text {th }}$ century and expected to kill 1 billion in the $21^{\text {st }}$ century (World Health Organization 2008). Cigarette smoking causes about 1 of every 5 deaths in the United States each year (Centers for Disease Control and Prevention (CDC) 2008, 200).

In Saudi Arabia an average of 600 million SR (approximately US\$ 150 millions) are spent annually on tobacco (Bassiony 2009). It is the fourth in the world in terms of tobacco sales and ranks $23^{\text {rd }}$ on the list of the world's highest consumers of tobacco (Al Moamary 2010), (Jarallah et al. 1996). Since tobacco consumption in students is affected by psychological, physical, emotional, and interpersonal relationships, tobacco companies use all available tactics to lure youth down a path of nicotine addiction and eventual death.

Various studies have reported that smoking and smokeless tobacco use start during adolescence (Office of the Surgeon General (US) and Office on Smoking and Health (US) 2004). According to the 2013 CDC report, $88 \%$ of adult smokers who smoke daily report that they started smoking by the age of 18 years ("Ash Action on Smoking and Health Fact Sheets Statistics: Illness and Death Introduction, Deaths Caused by Smoking, Non-Fatal Diseases , Resources" 2013). There is dearth in evidence regarding the prevalence of smoking among students especially adolescents in Saudi Arabia. It is to be noted that the most common approach to adolescent smoking prevention through school based educational programs. This cross-sectional study aims to analyze the prevalence of smoking among intermediate school students in Saudi Arabia and the effectiveness of an awareness program towards the cessation of the habit.

\section{LITERATURE REVIEW}

A cross-sectional study was conducted in January 2010 in Hamadan City, west of Iran. A random sample of 1161 high-school students were enrolled voluntarily. The data collection tool was a self-administered questionnaire that included demographic characteristics as well as questions about knowledge and attitude towards cigarette smoking. The prevalence of cigarette smoking was $10.2 \%$ with an increasing trend toward older ages. Of the 118 smokers, $70 \%$ were boys, $93 \%$ were 15 20 years old, $80 \%$ had experienced smoking before age of 15 years, $80.3 \%$ used less than five cigarettes per day, and 39\% started smoking out of curiosity. Students' mean scores of knowledge and attitude toward smoking were $53 \%$ and $74 \%$ respectively. Odds ratio estimate of becoming a smoker was 4.44 for those who lived with people other than their parents, 5.68 for those who had siblings who smoke, 10.74 for those who had friends who smoke and 12.56 for those who were frequently offered cigarettes by their friends.

Studies on the prevalence of smoking among students, especially adolescents were scarce in Saudi Arabia. In 1995, the prevalence of smoking in secondary school boys in Riyadh was $17 \%$ of the overall students, while in 1996, the prevalence was $13.3 \%$ and ranging from $3.2 \%$ for $12-13$ years old to $31.1 \%$ for 18-19 years old (al-Faris 1995), (Jarallah et al. 1996). In 2009, a literature review reported the prevalence of smoking in Saudi Arabia that ranged from $2.4 \%-52.3 \%$. Among school students, the prevalence of smoking varied from $12-29.8 \%$, among university students from $2.4-37 \%$, and among adults from 11.6-52.3\% (Bassiony 2009).

In 2011, two studies showed the prevalence of smoking among secondary school boys in Riyadh was $28.6 \%$ and $31.2 \%$ respectively (Al Nohair 2011), (Al Ghobain et al. 2011). The prevalence and characteristics of cigarette smoking among 16 to 18 
year-old boys and girls, in Jeddah was 37\% (Fida and Abdelmoneim 2013). There were only two studies in Saudi Arabia that included intermediate school students and revealed a smoking prevalence of $10.8 \%$ and $13.0 \%$ respectively (Albedah et al. 2011), (Al-Zalabani et al. 2015).

A cross-sectional study in Wales that included 1375 secondary students aged $15-16$ years demonstrated an association between policy strength, policy enforcement, and the prevalence of smoking among students. These findings suggest that the wider introduction of comprehensive school smoking policies may help reduce teenage smoking (Moore 2001).

Preventing Tobacco Use among Young People in India was a research used to assess the effectiveness of a 2-year multicomponent, school-based intervention designed to reduce tobacco-use rates among adolescents in an urban area of India. The sample consisted of students from 32 schools in Delhi and Chennai (India), who were recruited and randomly assigned to an intervention or control group. The baseline, intermediate, and outcome data were collected from two cohorts of 6th- and 8th-grade students in 2004; 14063 students took part in the study and completed a survey in 2004,2005 , or 2006 . The intervention consisted of behavioral classroom curricula, school posters, a parental involvement component, and peer-led activism. The main outcome measures were self-reported use of cigarettes, bidis (small hand-rolled, often flavored, cigarettes), chewing tobacco, and future intentions to smoke or use chewing tobacco. The findings showed that students in the intervention group were significantly less likely than their counterparts in the control group, to exhibit increase in cigarette smoking or bidi smoking over the 2-year study period. They were also less likely to have an intention towards smoking or chewing tobacco in the future (Perry et al. 2009).

\section{OBJECTIVES}

\section{General Objective}

To investigate the prevalence of cigarette-smoking among intermediate school students and to apply a smoking awareness program.

\section{Specific Objectives}

1. To study prevalence of cigarette-smoking among intermediate school students using GYTS questionnaire.

2. To assess knowledge of smoking risks and side effects through the GTYS questionnaire and the students' willingness of to quit smoking.

3. To study correlates of intermediate students' smoking.

4. To deliver a tobacco awareness message.

\section{MATERIALS AND METHODS}

\section{Target population}

Male intermediate school students in Jeddah, Saudi Arabia.

Study setting: Intermediate schools for boys in Jeddah (governmental, private and international).

Study design: Cross-sectional study.

\section{Sampling technique:}

\section{Sample Size:}

According to the Ministry of Education, students at intermediate schools for the year (1434-1435H) in Saudi Arabia, both females and males are 1212029 students. OpenEpi, Version 3.01, open source calculator with a confidence level of $95 \%, 35 \%$ prevalence of lifetime smoking and an allowable error of $6 \%$ yielded a required sample size of 243 (@ 300 students to control for non-response) (Kevin M. Sullivan, Dean, and Soe 2009) (Al-Bedah and Qureshi 2011). 


\section{Sample type and selection:}

A multi-stage stratified random sample with equal allocation was used. There were three types of schools; i.e., government, private and international schools. From each school type one school was selected randomly. In each selected school, one class was selected randomly from each grade (a total of three classes were selected) and all students within the selected classes were invited to participate in this study until the sample size was achieved.

\section{Data collection tools}

Data collection method was done by questionnaire including questions related to demographic data and the Global Youth Tobacco Survey (Al-Bedah and Qureshi 2011). Moreover, a screening of the oral cavity was done for all participants.

\section{Global Youth Tobacco Survey (GYTS)}

The GYTS (Global Youth Tobacco Survey Collaborative Group, 2012) is a school-based survey designed to enhance the capacity of countries to monitor tobacco-use among youth and to guide the implementation and evaluation of tobacco prevention and control programs. It is designed to gather information about smoking prevalence, knowledge, attitudes and behaviours related to tobacco-use, media, and advertising in addition to prevention activities in schools' curriculum. The information generated from the GYTS can be used to stimulate the development of tobacco control programs and can serve as a means to assess progress in meeting program goals. Our study employed the Global Youth Tobacco Survey (GYTS) Core Questionnaire which was composed of 43 "core" questions with five additional questions in our study considering mother/ father education, mother/father work, nationality and one item about gender was removed as our study included only boys. The items were designed to gather data on eight domains; student's background information (8 questions), use of tobacco (6 questions), student's feelings towards smoking cessation (4 questions), student's exposure to other people's smoking (7 questions), getting cigarettes
(4 questions), student's knowledge of messages that are against tobacco-use (4 questions), student's knowledge of advertisements or promotions for tobacco (5 questions), student's attitudes and beliefs about using tobacco (5 questions). Prior to the final administration of the questionnaire among the students, it was pretested among a pilot group (30 students) with similar characteristics. The questionnaire was modified and the final corrected version was used. The final questionnaire was distributed among students in the classroom in the absence of teachers or parents. The clinical exam forms were attached to the questionnaires. Each student returned the questionnaire to the clinical examiner to record the clinical exam on the same form.

\section{General oral examination}

The students received a general oral examination to identify their need for oral/dental health but not intended to be diagnostic. The examiner observed for plaque, gingivitis, caries and any oral mucosal lesions. This was done using mirror and explorer after calibration of examiners.

\section{Awareness intervention}

Following the completion of the questionnaire, a tobacco awareness brief PowerPoint presentation regarding the dangers and side effects of smoking was presented to all participants. At the end, an illustrated brochure was given to students in the efforts of providing them with required knowledge.

\section{Administrative design}

Approval was granted by the Minister of Education to acquire a consent for the questionnaire to be distributed at the school and general oral examination.

\section{Ethical Consideration}

The approval for this study was obtained from the ethical committee in King Abdul Aziz University, Faculty of Dentistry (KAUFD), Jeddah. Written consent was obtained from parents and informed oral 
consent was obtained from the students. Following the oral examination, an examination card was given to each student to regarding the dental-related services indicated for them. In addition, the phone number of KAUFD was listed on the card to help families call and schedule a screening appointment. The teachers were asked not to enter the classroom during both questionnaire administration and clinical examination to assure confidentiality of response result and to avoid response bias.

\section{Operational design}

After a preliminary visit to the school was conducted, the data was collected through a single field trip to each included school by King Abdul Aziz University Faculty of Dentistry (KAUFD) senior year male students. The inter-examiner and intraexaminer agreement was assessed and a cross check was done following collection of data between the groups to assure reliability of examination.

\section{Data Analysis}

Data were analyzed using SPSS, version 20.0 (SPSS Inc., Chicago, Illinois, USA). Descriptive statistics as mean, standard deviation, and proportion were used as indicated. Chi-square test was used to study the association between smoking and study variables. There is an accepted probability of $0.05 \%$ for obtaining such results by chance.

\section{RESULTS}

The study included 435 students [Table 1]; one third of them from private schools and the rest from government schools. Students were almost equally distributed over grades with an age range from 13-15 years. Most of them were Saudi nationals $(89.7 \%)$ and the remaining students were from other nationalities. In about $52 \%$ of the students, the fathers' education was below university-level, while in $60.7 \%$ students, the mothers' education was below university-level. The fathers were in employment for $86.7 \%$ of the students, while $25.3 \%$ of the students had working-mothers. The weekly pocket money for the majority of the students was less than 30 SR (83.7\%).

TABLE (1) Descriptive statistics on the demographic details of the study population

\begin{tabular}{|c|c|c|c|}
\hline \multicolumn{2}{|l|}{$(\mathrm{N}=435)$} & No. & $\%$ \\
\hline \multirow[t]{2}{*}{ School } & Governmental & 292 & 67.1 \\
\hline & Private & 143 & 32.9 \\
\hline \multirow[t]{3}{*}{ Class } & First & 150 & 34.5 \\
\hline & Second & 143 & 32.9 \\
\hline & Third & 142 & 32.6 \\
\hline \multirow[t]{3}{*}{ Age (years) } & 13 & 150 & 34.5 \\
\hline & 14 & 143 & 32.9 \\
\hline & 15 & 142 & 32.6 \\
\hline \multirow[t]{2}{*}{ Nationality } & Saudi & 390 & 89.7 \\
\hline & Non-Saudi & 45 & 10.3 \\
\hline \multirow[t]{2}{*}{ Father's education } & Below University & 224 & 51.5 \\
\hline & University or Higher & 211 & 48.5 \\
\hline \multirow[t]{2}{*}{ Mother's education } & Below University & 264 & 60.7 \\
\hline & University or Higher & 171 & 39.3 \\
\hline \multirow[t]{2}{*}{ Father's work } & Yes & 377 & 86.7 \\
\hline & No & 58 & 13.3 \\
\hline \multirow[t]{2}{*}{ Mother's work } & Yes & 110 & 25.3 \\
\hline & No & 325 & 74.7 \\
\hline \multirow{3}{*}{$\begin{array}{l}\text { Pocket money per } \\
\text { week (SR) }\end{array}$} & $<30$ & 364 & 83.7 \\
\hline & $30-$ & 27 & 6.2 \\
\hline & $50+$ & 44 & 10.1 \\
\hline
\end{tabular}

As shown in [Table 2], 33.1\% of the students have tried cigarettes, $30.6 \%$ of them started smoking at age 10 or $11,4.1 \%$ of the students smoked $1-2$ days last month. About $26.1 \%$ of smokers, smoked at least 1 cigarette per day last month. Also, $43.5 \%$ of smokers reported that they smoked occasionally in the morning and $23.9 \%$ smoked cigarettes within one hour from their last cigarette. 
TABLE (2) Prevalence of Tobacco-use among intermediate male students in Jeddah, Saudi Arabia

\begin{tabular}{|c|c|c|c|}
\hline Questions & Answers & No. & $\%$ \\
\hline \multirow{2}{*}{$\begin{array}{l}\text { Have you ever tried or experimented with } \\
\text { cigarette smoking, even one or two puffs? }\end{array}$} & Yes & 144 & 33.1 \\
\hline & No & 291 & 66.9 \\
\hline \multirow{6}{*}{$\begin{array}{l}\text { How old were you when you first tried a } \\
\text { cigarette? }\end{array}$} & 7 years old or younger & 20 & 13.9 \\
\hline & 8 or 9 years old & 12 & 8.3 \\
\hline & 10 or 11 years old & 44 & 30.6 \\
\hline & 12 or 13 years old & 25 & 17.4 \\
\hline & 14 or 15 years old & 38 & 26.4 \\
\hline & 16 years old or older & 5 & 3.5 \\
\hline \multirow{7}{*}{$\begin{array}{l}\text { During the past } 30 \text { days, on how many days } \\
\text { did you smoke cigarettes? }\end{array}$} & 0 days & 389 & 89.4 \\
\hline & 1 or 2 days & 18 & 4.1 \\
\hline & $3-5$ days & 8 & 1.8 \\
\hline & 6-9 days & 4 & .9 \\
\hline & 10-19 days & 4 & .9 \\
\hline & 20-29 days & 2 & .5 \\
\hline & All 30 days & 10 & 2.3 \\
\hline \multirow{6}{*}{$\begin{array}{l}\text { Please think about the days you smoked } \\
\text { cigarettes during the past } 30 \text { days. How } \\
\text { many cigarettes did you usually smoke per } \\
\text { day? }\end{array}$} & Less than 1 cigarette per day & 12 & 26.1 \\
\hline & 1 cigarette per day & 12 & 26.1 \\
\hline & 2 to 5 cigarettes per day & 13 & 28.3 \\
\hline & 6 to 10 cigarettes per day & 5 & 10.9 \\
\hline & 11 to 20 cigarettes per day & 2 & 4.3 \\
\hline & More than 20 cigarettes per day & 2 & 4.3 \\
\hline $\begin{array}{l}\text { Do you ever smoke tobacco or feel like } \\
\text { smoking tobacco first thing in the morning? }\end{array}$ & $\begin{array}{l}\text { No, I don't smoke tobacco or feel like } \\
\text { smoking tobacco first thing in the morning } \\
\text { Yes, I sometimes smoke tobacco or feel like } \\
\text { smoking tobacco first thing in the morning } \\
\text { Yes, I always smoke tobacco or feel like } \\
\text { smoking tobacco first thing in the morning }\end{array}$ & 20 & $\begin{array}{r}43.5 \\
43.5 \\
13.0\end{array}$ \\
\hline $\begin{array}{l}\text { How soon after you smoke tobacco do you } \\
\text { start to feel a strong desire to smoke again } \\
\text { that is hard to ignore? }\end{array}$ & $\begin{array}{l}\text { I never feel a strong desire to smoke again } \\
\text { after smoking tobacco } \\
\text { Within } 60 \text { minutes } \\
1 \text { to } 2 \text { hours } \\
\text { More than } 2 \text { hours to } 4 \text { hours } \\
\text { More than } 4 \text { hours but less than one full day } \\
1 \text { to } 3 \text { days } \\
4 \text { days or more }\end{array}$ & $\begin{array}{l}19 \\
11 \\
4 \\
4 \\
3 \\
2 \\
3\end{array}$ & $\begin{array}{r}41.3 \\
23.9 \\
8.7 \\
8.7 \\
6.5 \\
4.3 \\
6.5\end{array}$ \\
\hline
\end{tabular}


The intent towards smoking cessation was recorded with $87.0 \%$ of current smokers wishing to quit smoking immediately, $78.3 \%$ of them had tried to quit smoking last year and $87.0 \%$ of smokers think they could quit smoking if they intend on doing it. The majority of the students (74.3\%) felt that they had no advice to help them quit smoking [Table 3].

About $11.5 \%$ of the students had someone who smoked every day at his home last week, $22.5 \%$ of the student had someone who smoked 1-2 day's in closed public places last week, $24.6 \%$ of the student had someone who smoked 1-2 day's outdoor last week and $29 \%$ of the students have seen other students smoking in the school building. Considering students' attitude of passive smoking, $66.4 \%$ of them are sure that passive smoking can affect them, $76.3 \%$ of the student agreed against indoor smoking, and $67.4 \%$ of the student agreed against smoking in public spaces [Table 4].

TABLE (3) Descriptive statistics on the intent towards smoking cessation among intermediate male students in Jeddah

\begin{tabular}{|l|l|l|l|}
\hline Questions & Answers & No. & $\%$ \\
\hline Do you want to stop smoking now? & Yes & 40 & 87.0 \\
& No & 6 & 13.0 \\
\hline During the past 12 months, did you ever try to stop & Yes & 36 & 78.3 \\
smoking? & No & 10 & 21.7 \\
\hline Do you think you would be able to stop smoking if you & Yes & 40 & 87.0 \\
wanted to? & No & 6 & 13.0 \\
\hline Have you ever received help or advice to help you stop & Yes from program or a person & 2 & 1.4 \\
smoking? & Yes from a friend & 19 & 13.2 \\
& Yes from a family member & 9 & 6.3 \\
& Yes all of the above & 7 & 4.9 \\
\hline
\end{tabular}

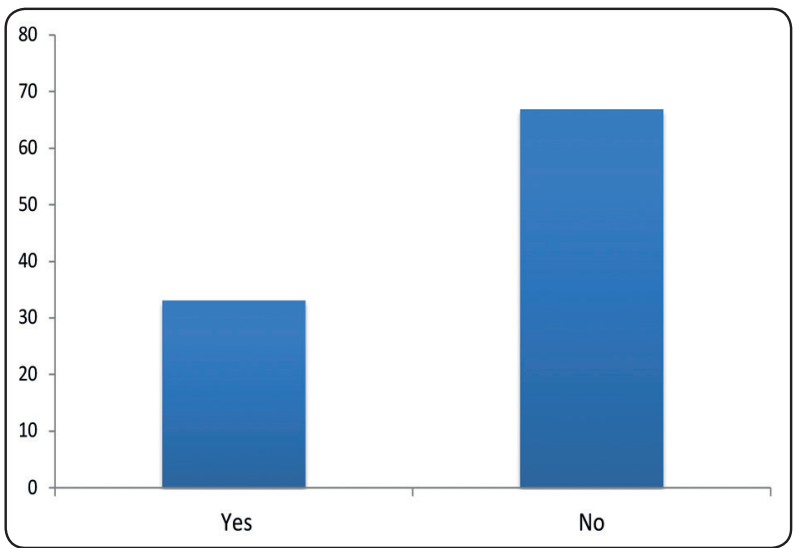

Fig. (1) Ever Use of Tobacco among male intermediate school students in Jeddah, Saudi Arabia

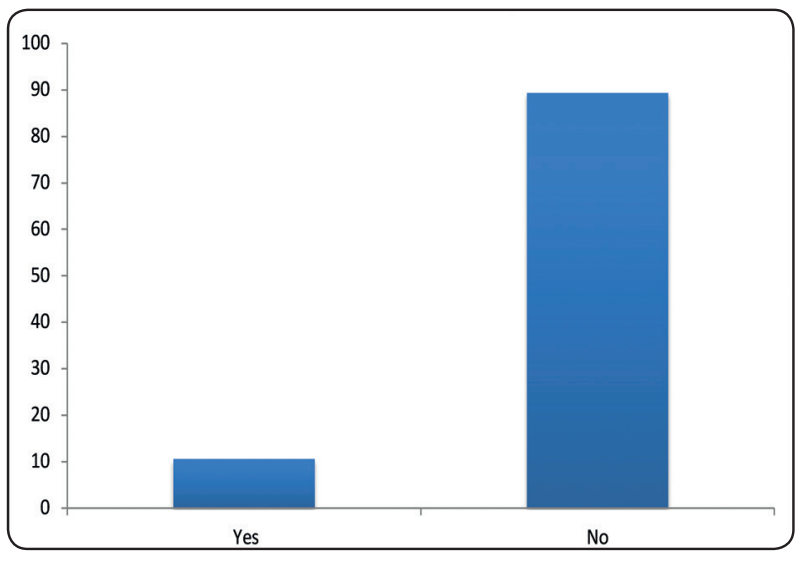

Fig. (2) Current Use of Tobacco among male intermediate school students in Jeddah, Saudi Arabia 
TABLE (4) Descriptive statistics on the students' exposure to other people's smoking (Passive smoking

\begin{tabular}{|c|c|c|c|}
\hline Question & Answers & No. & $\%$ \\
\hline $\begin{array}{l}\text { During the past } 7 \text { days, on how many days has anyone smoked inside } \\
\text { your home, in your presence? }\end{array}$ & $\begin{array}{l}\text { Never } \\
\text { 1-2 Days } \\
\text { 3-4 Days } \\
\text { 5-6 Days } \\
\text { 7 Days }\end{array}$ & $\begin{array}{l}326 \\
36 \\
14 \\
9 \\
50\end{array}$ & $\begin{array}{l}74.9 \\
8.3 \\
3.2 \\
2.1 \\
11.5\end{array}$ \\
\hline $\begin{array}{l}\text { During the past } 7 \text { days, on how many days has anyone smoked in } \\
\text { your presence, inside any enclosed public place, other than your } \\
\text { home? }\end{array}$ & $\begin{array}{l}\text { Never } \\
\text { 1-2 Days } \\
\text { 3-4 Days } \\
\text { 5-6 Days } \\
\text { 7 Days }\end{array}$ & $\begin{array}{l}241 \\
98 \\
35 \\
18 \\
43\end{array}$ & $\begin{array}{l}55.4 \\
22.5 \\
8.0 \\
4.1 \\
9.9\end{array}$ \\
\hline $\begin{array}{l}\text { During the past } 7 \text { days, on how many days has anyone smoked in } \\
\text { your presence, at any outdoor public place? }\end{array}$ & $\begin{array}{l}\text { Never } \\
\text { 1-2 Days } \\
\text { 3-4 Days } \\
\text { 5-6 Days } \\
\text { 7 Days }\end{array}$ & $\begin{array}{l}196 \\
107 \\
48 \\
19 \\
65\end{array}$ & $\begin{array}{l}45.1 \\
24.6 \\
11.0 \\
4.4 \\
14.9\end{array}$ \\
\hline $\begin{array}{l}\text { During the past } 30 \text { days, did you see anyone smoke inside the school } \\
\text { building or outside on school property? }\end{array}$ & $\begin{array}{l}\text { No } \\
\text { Yes }\end{array}$ & $\begin{array}{l}309 \\
126\end{array}$ & $\begin{array}{l}71.0 \\
29.0\end{array}$ \\
\hline $\begin{array}{l}\text { Do you think the smoke from other people's tobacco smoking is } \\
\text { harmful to you? }\end{array}$ & $\begin{array}{l}\text { Definitely No } \\
\text { Maybe No } \\
\text { Maybe Yes } \\
\text { Definitely Yes }\end{array}$ & $\begin{array}{l}48 \\
14 \\
84 \\
289\end{array}$ & $\begin{array}{l}11.0 \\
3.2 \\
19.3 \\
66.4\end{array}$ \\
\hline Are you in favor of banning smoking inside enclosed public places? & $\begin{array}{l}\text { Yes } \\
\text { No }\end{array}$ & $\begin{array}{l}332 \\
103\end{array}$ & $\begin{array}{l}76.3 \\
23.7\end{array}$ \\
\hline Are you in favor of banning smoking at outdoor public places? & $\begin{array}{l}\text { Yes } \\
\text { No }\end{array}$ & $\begin{array}{l}293 \\
142\end{array}$ & $\begin{array}{l}67.4 \\
32.6\end{array}$ \\
\hline
\end{tabular}

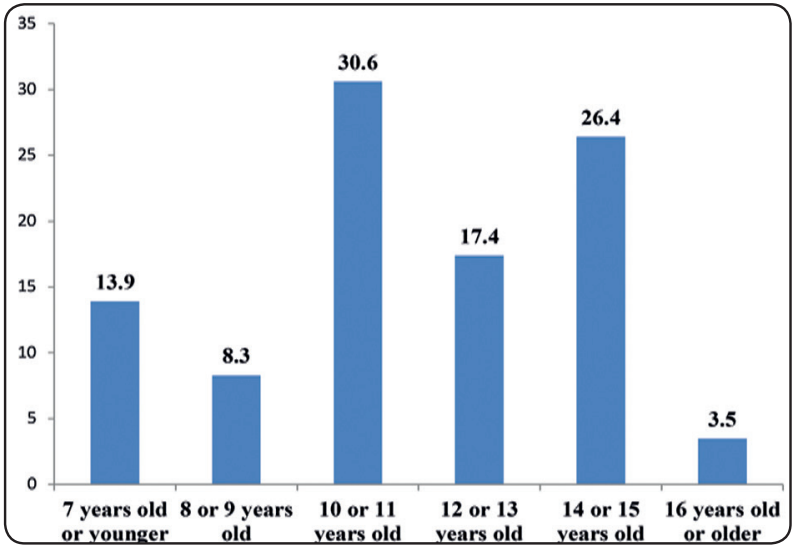

Fig. (3) Start age of tobacco-use among male intermediate school students (Ever-users) in Jeddah, Saudi Arabia
Students who bought cigarettes from a store constituted $76.1 \%$ of smokers, $63.0 \%$ of smokers had no age problem for buying cigarettes last month, $69.6 \%$ of them bought a packet of cigarettes last month and $69.6 \%$ of the students were aware of the cost of a single cigarette pack (5-10 SAR) [Table 5]. [Table 6] showed that $70.6 \%$ of students have seen anti-tobacco media messages last month, only $14.5 \%$ reported that it guided them against the smoking habit and $33.6 \%$ agreed that they were taught in the classes about dangers of tobacco use. 
It was reported that $57.9 \%$ of the students had seen people using tobacco in media content such as TV, videos, or movies, $23.9 \%$ have seen advertisements or promotions for tobacco products at points of sale. To understand the students' mindset on promotion of tobacco products, $10.3 \%$ agreed that they would wear something that has a tobacco company/product name/picture, whereas, $9.9 \%$ of students have something with a tobacco product brand logo on it. About $9.4 \%$ students reported that an employee of a tobacco company had offered them with a free tobacco product.

TABLE (5) Descriptive statistics on the modes of procurement of cigarettes among intermediate male students in Jeddah, Saudi Arabia.

\begin{tabular}{|l|l|c|c|}
\hline Question & Answers & No. & $\%$ \\
\hline The last time you smoked cigarettes & From a store & 35 & 76.1 \\
during the past 30 days, how did you get & From street seller & 2 & 4.3 \\
them? & Another person & 4 & 8.7 \\
& Other & 5 & 10.9 \\
\hline During the past 30 days, did anyone refuse & Yes from a store and the seller refused for my age & 17 & 37.0 \\
to sell you cigarettes because of your age? & No my age was not an obstacle & 29 & 63.0 \\
\hline The last time you bought cigarettes during & By packet & 32 & 69.6 \\
the past 30 days, how did you buy them? & By piece & 8 & 17.4 \\
& By package & 3 & 1 \\
& By rolled tobacco & 2.5 \\
\hline On average, how much do you think a & Rolled the tobacco by my self & Bought by piece & 8.3 \\
pack of 20 cigarettes costs? & 5-10 SAR & 32 & 69.6 \\
& More than 10 SAR & 6 & 13.0
\end{tabular}

TABLE (6) Knowledge awareness of messages against tobacco-use among intermediate male students in Jeddah, Saudi Arabia

\begin{tabular}{|c|c|c|c|}
\hline Questions & Answer & No. & $\%$ \\
\hline $\begin{array}{l}\text { During the past } 30 \text { days, did you see or hear any anti- } \\
\text { tobacco media messages on television, radio, internet, } \\
\text { billboards, posters, newspapers, magazines, or movies? }\end{array}$ & $\begin{array}{l}\text { Yes } \\
\text { No }\end{array}$ & $\begin{array}{l}307 \\
128\end{array}$ & $\begin{array}{l}70.6 \\
29.4\end{array}$ \\
\hline $\begin{array}{l}\text { During the past } 30 \text { days, did you see or hear any anti- } \\
\text { tobacco messages at sports events, fairs, concerts, or } \\
\text { community events, or social gatherings? }\end{array}$ & $\begin{array}{l}\text { Did not attend sport events last month } \\
\text { Yes } \\
\text { No }\end{array}$ & $\begin{array}{l}194 \\
133 \\
108\end{array}$ & $\begin{array}{l}44.6 \\
30.6 \\
24.8\end{array}$ \\
\hline $\begin{array}{l}\text { During the past } 30 \text { days, did you see any health warnings on } \\
\text { cigarette packages? }\end{array}$ & $\begin{array}{l}\text { Yes and did not think about it } \\
\text { Yes and guide me to quit smoking or } \\
\text { not smoking } \\
\text { No }\end{array}$ & $\begin{array}{c}225 \\
63 \\
147\end{array}$ & $\begin{array}{l}51.7 \\
14.5 \\
33.8\end{array}$ \\
\hline $\begin{array}{l}\text { During the past } 12 \text { months, were you taught in any of } \\
\text { your classes about the dangers of tobacco use? }\end{array}$ & $\begin{array}{l}\text { Yes } \\
\text { No } \\
\text { I don't know }\end{array}$ & $\begin{array}{c}146 \\
213 \\
76\end{array}$ & $\begin{array}{l}33.6 \\
49.0 \\
17.5\end{array}$ \\
\hline
\end{tabular}


About $77.0 \%$ of the students responded that they will never use tobacco and most of them disagree with the statement "I think I might enjoy smoking a cigarette." It is to be noted that $80 \%$ of the students did not feel compelled to smoke a cigarette because of peer-pressure [Table 8].

TABLE (7) Knowledge awareness on the advertisements and promotions for tobacco products among intermediate male students in Jeddah, Saudi Arabia

\begin{tabular}{|c|c|c|c|}
\hline Questions & Answer & No. & $\%$ \\
\hline $\begin{array}{l}\text { During the past } 30 \text { days, did you see any people using } \\
\text { tobacco when you watched TV, videos, or movies? }\end{array}$ & $\begin{array}{l}\text { Did not watch TV last month } \\
\text { Yes } \\
\text { No }\end{array}$ & $\begin{array}{c}51 \\
252 \\
132\end{array}$ & $\begin{array}{l}11.7 \\
57.9 \\
30.3\end{array}$ \\
\hline $\begin{array}{l}\text { During the past } 30 \text { days, did you see any advertisements or } \\
\text { promotions for Tobacco products at points of sale? }\end{array}$ & $\begin{array}{l}\text { Did not visit any store } \\
\text { Yes } \\
\text { No }\end{array}$ & $\begin{array}{l}111 \\
104 \\
220\end{array}$ & $\begin{array}{l}25.5 \\
23.9 \\
50.6\end{array}$ \\
\hline $\begin{array}{l}\text { Would you ever use or wear something that has a tobacco } \\
\text { company or tobacco product name or picture on it such as } \\
\text { a lighter, t-shirt, hat, or sunglasses? }\end{array}$ & $\begin{array}{l}\text { Yes } \\
\text { Maybe } \\
\text { No }\end{array}$ & $\begin{array}{c}45 \\
78 \\
312\end{array}$ & $\begin{array}{l}10.3 \\
17.9 \\
71.7\end{array}$ \\
\hline $\begin{array}{l}\text { Do you have something (for example, t-shirt, pen, } \\
\text { backpack) with a tobacco product brand logo on it? }\end{array}$ & $\begin{array}{l}\text { Yes } \\
\text { No }\end{array}$ & $\begin{array}{c}43 \\
392\end{array}$ & $\begin{array}{c}9.9 \\
90.1\end{array}$ \\
\hline $\begin{array}{l}\text { Has a person working for a tobacco company ever offered } \\
\text { you a free tobacco product? }\end{array}$ & $\begin{array}{l}\text { Yes } \\
\text { No }\end{array}$ & $\begin{array}{c}41 \\
394\end{array}$ & $\begin{array}{c}9.4 \\
90.6\end{array}$ \\
\hline
\end{tabular}

TABLE (8) Attitudes and beliefs about using tobacco by intermediate male students in Jeddah, Saudi Arabia

\begin{tabular}{|c|c|c|c|}
\hline Questions & Answer & No. & $\%$ \\
\hline $\begin{array}{l}\text { If one of your best friends offered you a tobacco product, would you use } \\
\text { it? }\end{array}$ & $\begin{array}{l}\text { Definitely No } \\
\text { Maybe No } \\
\text { Maybe Yes } \\
\text { Definitely Yes }\end{array}$ & $\begin{array}{c}348 \\
43 \\
29 \\
15 \\
\end{array}$ & $\begin{array}{c}80.0 \\
9.9 \\
6.7 \\
3.4 \\
\end{array}$ \\
\hline $\begin{array}{l}\text { At any time during the next } 12 \text { months do you think you will use any } \\
\text { form of tobacco? }\end{array}$ & $\begin{array}{l}\text { Definitely No } \\
\text { Maybe No } \\
\text { Maybe Yes } \\
\text { Definitely Yes } \\
\end{array}$ & $\begin{array}{c}335 \\
40 \\
45 \\
15 \\
\end{array}$ & $\begin{array}{c}77.0 \\
9.2 \\
10.3 \\
3.4 \\
\end{array}$ \\
\hline $\begin{array}{l}\text { Once someone has started smoking tobacco, do you think it would be } \\
\text { difficult for them to quit? }\end{array}$ & $\begin{array}{l}\text { Definitely No } \\
\text { Maybe No } \\
\text { Maybe Yes } \\
\text { Definitely Yes } \\
\end{array}$ & $\begin{array}{c}109 \\
83 \\
142 \\
101 \\
\end{array}$ & $\begin{array}{l}25.1 \\
19.1 \\
32.6 \\
23.2\end{array}$ \\
\hline $\begin{array}{l}\text { Do you think smoking tobacco helps people feel more comfortable or } \\
\text { less comfortable at celebrations, parties, or in other social gatherings? }\end{array}$ & $\begin{array}{l}\text { More relaxed } \\
\text { Less Relaxed } \\
\text { No Difference }\end{array}$ & $\begin{array}{c}80 \\
193 \\
162 \\
\end{array}$ & $\begin{array}{l}18.4 \\
44.4 \\
37.2 \\
\end{array}$ \\
\hline $\begin{array}{l}\text { Do you agree or disagree with the following: "I think I might enjoy } \\
\text { smoking a cigarette?" }\end{array}$ & \begin{tabular}{|l} 
I smoke currently \\
Strongly agree \\
Agree \\
Disagree \\
Strongly disagree
\end{tabular} & $\begin{array}{c}28 \\
20 \\
27 \\
108 \\
252\end{array}$ & $\begin{array}{c}6.4 \\
4.6 \\
6.2 \\
24.8 \\
57.9\end{array}$ \\
\hline
\end{tabular}


The correlates of ever use and current use of cigarettes among students were evaluated and the factors with high statistical significance were age (p-value-0.005) and pocket money per week (p-value-0.000) [Table 9]. Older children and those with 50 SR or more pocket money per week had significantly higher prevalence of smoking. Untreated cavities constituted $76.2 \%$ in primary teeth and $65.7 \%$ in permanent teeth, gingival inflammation $(69 \%)$, poor oral hygiene in $30.1 \%$ and $9.2 \%$ required urgent dental care [Table 10].

TABLE (9) Pearson Correlation test for the correlation between ever users and current users of smoking with their demographic background among intermediate male students in Jeddah, Saudi Arabia

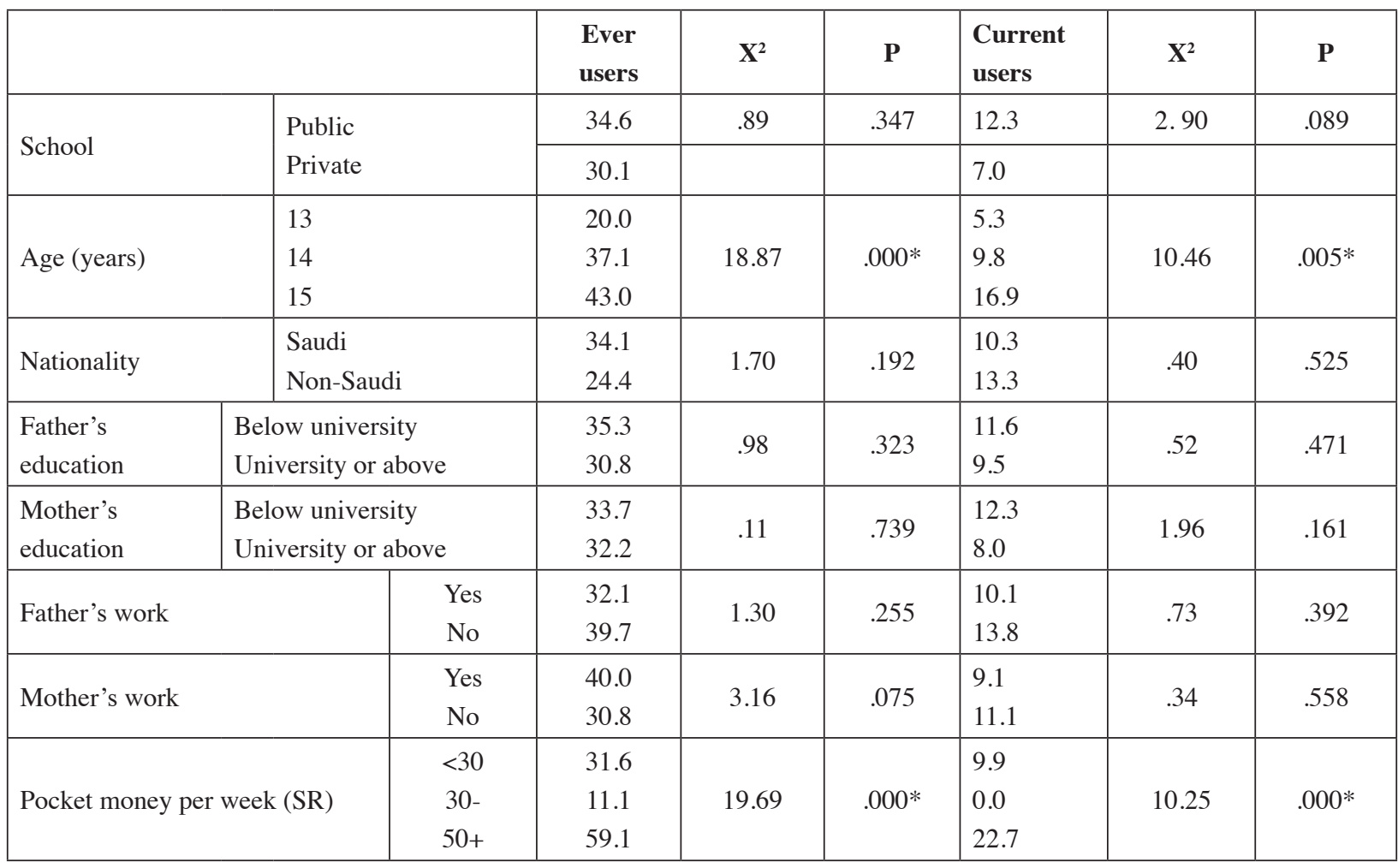

\section{$* P<0.05$ (Significant)}

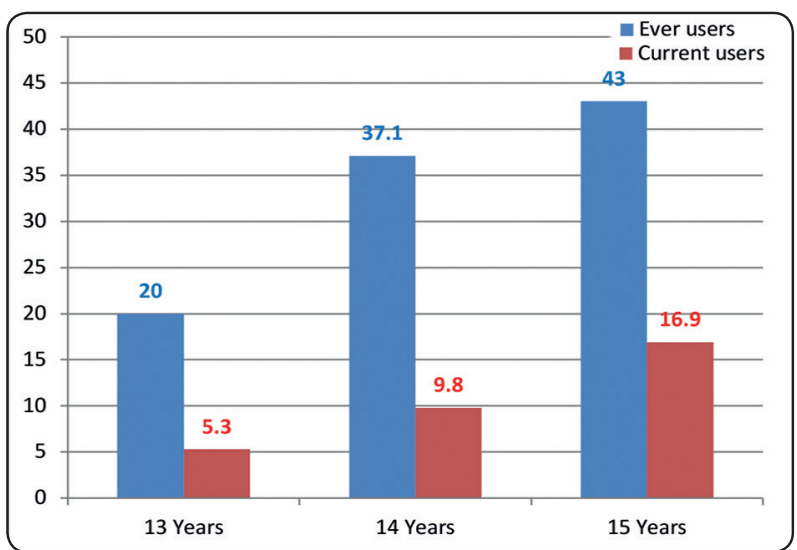

Fig. (4) Percentage of ever users and current users of tobacco by Age

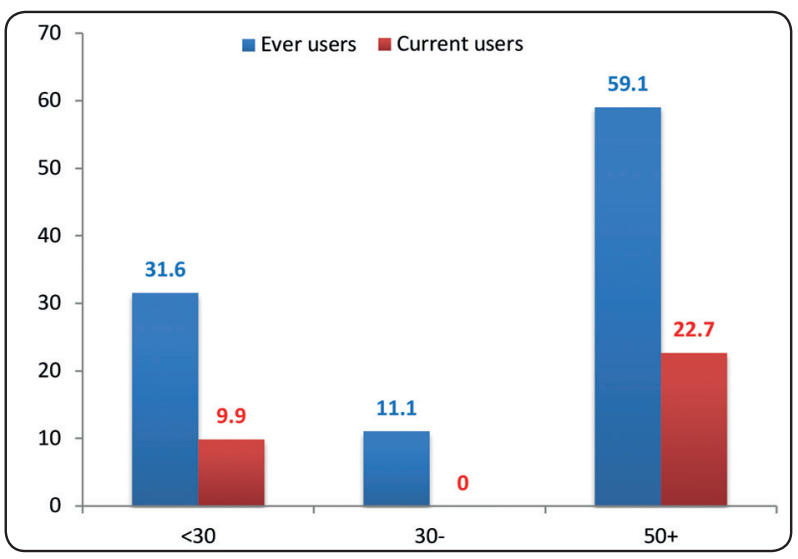

Fig. (5) Ever users and current users of tobacco by pocket money per week 
TABLE (10) Descriptive statistics on the Oral Health problems among Intermediate students in Jeddah, Saudi Arabia

\begin{tabular}{|l|l|c|c|}
\hline & & No. & \% \\
\hline Untreated Cavities & No cavities & 5 & 23.8 \\
Primary Teeth & Untreated cavities & 16 & 76.2 \\
\hline Untreated Cavities: & No cavities & 149 & 34.3 \\
Permanent Teeth & Untreated cavities & 286 & 65.7 \\
\hline Gingival inflammation & No & 135 & 31.0 \\
& Yes & 300 & 69.0 \\
\hline Oral Hygiene: & Good & 103 & 23.7 \\
& Fair & 201 & 46.2 \\
& Poor & 131 & 30.1 \\
\hline Treatment Urgency: & No abnormality detected & 187 & 43.0 \\
& Early dental care & 208 & 47.8 \\
& Urgent care & 40 & 9.2 \\
\hline
\end{tabular}

\section{DISCUSSION}

This cross-sectional study was performed on 435 adolescents (13-15 years male) in Jeddah, Saudi Arabia with the approval from the Ministry of Education towards the evaluation of the prevalence of smoking habit among the students in different types of schools (private, government, international). The majority of the students belonged to government schools and a self-administered GYTS questionnaire was employed to assess the tobacco-usage and awareness on smoking among the school students. The prevalence of smoking was estimated from this study to be about $33.1 \%$ which included students who have tried or experimented with cigarette smoking. In 2007, Global Youth Tobacco Survey was conducted among 13-15-yearold students in Saudi Arabia and the prevalence was estimated to be $6.7 \%$ with an average response rate of $82.1 \%$. It can be noted that there is a dramatic increase in the prevalence rates of the two studies and our study results are concomitant with the fact that boys were more likely to be current smokers for cigarettes as well as other tobacco-related products (Moh'd Al-Mulla et al. 2008), (Warren et al. 2008).
In this study, it was showed that there were regular smokers with $26.1 \%$ who smoke at least 1 cigarette/ day, 28.3\% smoked 2-5 cigarettes/day, and about $4.3 \%$ smoked 11-20 and more than 20 cigarettes/ day in the last 30 days. This is in stark contrast to a school-based survey conducted in China that $0.3 \%$ of the students excluding girls were regular smokers who smoked at least 1 cigarette per day (Hesketh, Ding, and Tomkins 2001). This data shows that the number of adolescent regular smokers in Saudi Arabia were higher when compared to a developing nation like China. But, the intention towards smoking cessation with immediate effect was observed in $87 \%$ of the current smokers in this study. This value is considerably higher than reported in two studies conducted among adolescents in Hong Kong and Cyprus with $51 \%$ and $46.1 \%$ respectively (Wong et al. 2010), (Savvides et al. 2014). It is also significantly higher than the values observed in study that was conducted among adolescents in Al, Madinah Saudi Arabia that showed $71.7 \%$ of the current student smokers intended to quit the habit within one year (Abdulmohsen Hamdan, Ayat Roushdy, and Reem Ibrahim 2015). 
A strong predictor of adolescent smoking is parental smoking and the odds are significantly higher when both parents smoke (2.05 vs 1.24$)$ (Xie et al. 2013), (El-Amin et al. 2011). The studies further emphasized that adolescents were more likely to smoke when the mothers smoked and girls were more affected to this tendency when compared to the boys (Leonardi-Bee, Jere, and Britton 2011), (Kelli Maud Sullivan, Bottorff, and Reid 2011). In our study, it was showed that about $11.5 \%$ of the students had someone who smoked every day in their houses for the last week. It was also observed that $29 \%$ students witnessed other students smoking in the building. These findings reinforce the predictors of adolescent smoking and in this study, the demographic characteristics showed that in half of the student population (52\%), the fathers' education was below university-level, whereas in $60.7 \%$ of the cases, the mothers' education was not up to university-level. This could also have a significant effect on adolescent smoking and its roots are to be understood further with future trials.

House-hold smoking bans by family members and bans in public places are to be enforced and the protocol should be strict, so that people with intention to quit head in the right direction. Both the bans should be taken seriously because bans in public places increases the likelihood of household smoking and vice versa (Wong et al. 2010). In our study, it was reported that $76.3 \%$ of the students agreed to indoor banning whereas, $67.4 \%$ of the students agreed to smoking bans in public places. It can be deduced that the mindset of the students was towards smoking cessation and enforcing these bans may have a positive effect on these students.

In this study, the smoking habit may have been developed through the following medium with more than half of the student population (57.9\%) having seen media content with people using tobacco and $9.4 \%$ received a free tobacco product from an employee of a tobacco company. It is prudent to note that anti-smoking social messages as well as awareness campaigns should aim to inculcate means to quit the habit at an early age. This study also observed that $74.3 \%$, a significant proportion of the student population felt that they had no advice towards guiding them in smoking cessation.

Passive smoking poses a significant public health hazard and it poses a greater risk to neversmoking adolescents. A study conducted in China showed that there were increased odds (OR-2.05) of current smoking in adolescents who were exposed to secondhand smoke (Wang et al. 2016). In this study, there was increased awareness among students towards passive smoking with $66.4 \%$ of the students agreeing that second smoke could affect them. It is also worth noting that about $80 \%$ of the student population did not feel compelled to smoke a cigarette because of peer-pressure. This further reinforces the significant role that an aware nonsmoker could play in the life of a smoking adolescent motivating him/her to quit when connected in their social circle.

A correlation test revealed that older adults and higher pocket money per week were significant influencers in adolescent smoking. Also, it was shown from the clinical examination that there were $76.2 \%$ untreated cavities in primary teeth and $65.7 \%$ in the permanent teeth. Gingival inflammation was observed in $69 \%$ and $30.1 \%$ with poor oral hygiene. About half of the population required early dental care with $9.2 \%$ needing urgent care. A study conducted among Swedish adolescents showed that there was increased risk of caries with tobacco use and the DMFS rates varied between ever and never users (1.8 vs 1.2) (Holmén et al. 2013). It has been shown that cigarette smoking poses a higher risk of periodontal destruction in the younger population (Mullally 2004).

This study provided a brief awareness program at the end of the questionnaire session but a feedback was not received from the students to understand the effectiveness. The other limitations of this study include its cross-sectional design and the multiple predictive factors for adolescent smoking assessed 
from this study can be ascertained using future longitudinal cohort studies. Smoking has been associated with significant morbidity and mortality, and younger age group have profound destructive effects. Saudi Arabia has been ranked fourth in the world for cigarette imports and with the faster growing number of adolescent smokers, it is vital to develop awareness programs towards smoking, its implications on health, and smoking cessation.

\section{CONCLUSION}

This study was conducted among male intermediate school students in Saudi Arabia and a prevalence of $33.1 \%$ was observed. It was observed that there was a higher proportion of regular smokers and the majority of the student population had an intention to quit the habit. The students were aware that passive smoking can affect them and most of the students were in favor of smoking bans in house-hold as well as public places. Peer-pressure did not influence the students but the media visuals with people smoking had a stronger influence on the students. The correlates for never and ever smokers were older age group and higher pocket money, and the oral health of the students showed higher incidence of caries, gingival inflammation, and some proportion of the student population required urgent dental care. Future studies are warranted towards ascertaining the causal as well as influencing factors deduced from this study and stronger anti-smoking awareness campaigns are the need-of-the-hour for the rising numbers of adolescent smokers in the kingdom of Saudi Arabia.

\section{REFERENCES}

1. Abdulmohsen Hamdan, Al-Zalabani, Abdallah Ayat Roushdy, and Alqabshawi Reem Ibrahim. 2015. "Intention to Quit Smoking among Intermediate and Secondary School Students in Saudi Arabia." Asian Pacific Journal of Cancer Prevention 16 (15): 6741-47. https://doi. org/10.7314/APJCP.2015.16.15.6741.

2. Al Ghobain, Mohammed O., Mohamed S. Al Moamary, Sulieman N. Al Shehri, and Mohamed S. Al-Hajjaj. 2011.
"Prevalence and Characteristics of Cigarette Smoking among 16 to 18 Years Old Boys and Girls in Saudi Arabia." Annals of Thoracic Medicine 6 (3): 137-40. https:// doi.org/10.4103/1817-1737.82447.

3. Al Moamary, MohamedS. 2010. "Tobacco Consumpation: Is Still a Dilemma?" Annals of Thoracic Medicine 5 (4): 193. https://doi.org/10.4103/1817-1737.69103.

4. Al Nohair, Sultan Fahad. 2011. "Prevalence of Smoking and Its Related Behaviors and Beliefs among Secondary School Students in Riyadh, Saudi Arabia.” International Journal of Health Sciences 5 (1): 51-57.

5. Albedah, Abdullah M., Mohamed K. Khalil, Asim A. Khalil, and Ahmed T. Elolemy. 2011. "Use of the Target Group Index Survey to Evaluate the Cigarette Smoking Profile in Saudi Arabia." Saudi Medical Journal 32 (10): 1055-59.

6. Al-Bedah, Abdullah Mohammed, and Naseem Akhtar Qureshi. 2011. "The Global Youth Tobacco Survey: 20012002 in Riyadh Region, the Kingdom of Saudi Arabia." Substance Abuse and Rehabilitation 2: 197-204. https:// doi.org/10.2147/SAR.S23626.

7. Al-Zalabani, Abdulmohsen H., Soliman M. Amer, Khaled A. Kasim, Reem I. Alqabshawi, and Ayat R. Abdallah. 2015. "Second-Hand Smoking among Intermediate and Secondary School Students in Madinah, Saudi Arabia." BioMed Research International 2015: 1-8. https://doi. org/10.1155/2015/672393.

8. "Ash Action on Smoking and Health Fact Sheets Statistics: Illness and Death Introduction, Deaths Caused by Smoking, Non Fatal Diseases , Resources.” 2013.

9. Bala, Malgorzata M, Lukasz Strzeszynski, Roman ToporMadry, and Kate Cahill. 2013. "Mass Media Interventions for Smoking Cessation in Adults." Edited by Cochrane Tobacco Addiction Group. Cochrane Database of Systematic Reviews, June. https://doi.org/10.1002/14651858. CD004704.pub3.

10. Bassiony, Medhat M. 2009. "Smoking in Saudi Arabia." Saudi Medical Journal 30 (7): 876-81.

11. Centers for Disease Control and Prevention (CDC). 2008. "Smoking-Attributable Mortality, Years of Potential Life Lost, and Productivity Losses--United States, 2000-2004." MMWR. Morbidity and Mortality Weekly Report 57 (45): 1226-28. 
12. El-Amin, Salma El-Tayeb, Bright I. Nwaru, Ibrahim Ginawi, Paola Pisani, and Matti Hakama. 2011. "The Role of Parents, Friends and Teachers in Adolescents' Cigarette Smoking and Tombak Dipping in Sudan." Tobacco Control 20 (2): 94-99. https://doi.org/10.1136/tc.2010.038091.

13. Faris, E. A. al-. 1995. "Smoking Habits of Secondary School Boys in Rural Riyadh.” Public Health 109 (1): 4755. https://doi.org/10.1016/s0033-3506(95)80075-1.

14. Fida, Hashim R, and Ismail Abdelmoneim. 2013. "Prevalence of Smoking among Secondary School Male Students in Jeddah, Saudi Arabia: A Survey Study.” BMC Public Health 13 (1). https://doi.org/10.1186/1471-245813-1010.

15. Hesketh, T., Q. J. Ding, and A. Tomkins. 2001. "Smoking among Youths in China." American Journal of Public Health 91 (10): 1653-55. https://doi.org/10.2105/ ajph.91.10.1653.

16. Holmén, Anders, Ulf Strömberg, Kerstin Magnusson, and Svante Twetman. 2013. "Tobacco Use and Caries Risk among Adolescents--a Longitudinal Study in Sweden.” BMC Oral Health 13 (July): 31. https://doi. org/10.1186/1472-6831-13-31.

17. Jarallah, J. S., E. A. Bamgboye, L. A. al-Ansary, and K. A. Kalantan. 1996. "Predictors of Smoking among Male Junior Secondary School Students in Riyadh, Saudi Arabia." Tobacco Control 5 (1): 26-29. https://doi. org/10.1136/tc.5.1.26.

18. Leonardi-Bee, Jo, Mirriam Lisa Jere, and John Britton. 2011. "Exposure to Parental and Sibling Smoking and the Risk of Smoking Uptake in Childhood and Adolescence: A Systematic Review and Meta-Analysis." Thorax 66 (10): 847-55. https://doi.org/10.1136/thx.2010.153379.

19. Moh'd Al-Mulla, Ahmad, Sahar Abdou Helmy, Jawad AlLawati, Sami Al Nasser, Salah Ali Abdel Rahman, Ayesha Almutawa, Bassam Abi Saab, et al. 2008. "Prevalence of Tobacco Use Among Students Aged 13-15 Years in Health Ministers' Council/Gulf Cooperation Council Member States, 2001-2004." Journal of School Health 78 (6): 33743. https://doi.org/10.1111/j.1746-1561.2008.00311.x.

20. Moore, L. 2001. "School Smoking Policies and Smoking Prevalence among Adolescents: Multilevel Analysis of Cross-Sectional Data from Wales." Tobacco Control 10 (2): 117-23. https://doi.org/10.1136/tc.10.2.117.

21. Mullally, Brian H. 2004. "The Influence of Tobacco Smoking on the Onset of Periodontitis in Young Persons." Tobac- co Induced Diseases 2 (1): 6. https://doi.org/10.1186/16179625-2-6.

22. Office of the Surgeon General (US), and Office on Smoking and Health (US). 2004. The Health Consequences of Smoking: A Report of the Surgeon General. Reports of the Surgeon General. Atlanta (GA): Centers for Disease Control and Prevention (US). http://www.ncbi.nlm.nih. gov/books/NBK44695/.

23. Perry, Cheryl L., Melissa H. Stigler, Monika Arora, and K. Srinath Reddy. 2009. "Preventing Tobacco Use among Young People in India: Project MYTRI.” American Journal of Public Health 99 (5): 899-906. https://doi.org/10.2105/ AJPH.2008.145433.

24. Savvides, Elena Charis G., Costas A. Christophi, Martha Paisi, Despina Pampaka, Taru Kinnunen, and Gregory N. Connolly. 2014. "Factors Associated with Intent to Quit Tobacco Use in Cyprus Adolescents." Preventive Medicine 60 (March): 83-87. https://doi.org/10.1016/j. ypmed.2013.12.016.

25. Sullivan, Kelli Maud, Joan Bottorff, and Colin Reid. 2011. “Does Mother's Smoking Influence Girls' Smoking More than Boys' Smoking? A 20-Year Review of the Literature Using a Sex- and Gender-Based Analysis.” Substance Use \& Misuse 46 (5): 656-68. https://doi.org/10.3109/108260 84.2010 .528122 .

26. Sullivan, Kevin M., Andrew Dean, and Minn Minn Soe. 2009. "OpenEpi: A Web-Based Epidemiologic and Statistical Calculator for Public Health." Public Health Reports (Washington, D.C.: 1974) 124 (3): 471-74. https:// doi.org/10.1177/003335490912400320.

27. The W. 1999. "Curbing the Epidemic: Governments and the Economics of Tobacco Control." 8 (2): 196.

28. Wang, Meng, Jie-Ming Zhong, Le Fang, and Hao Wang. 2016. "Prevalence and Associated Factors of Smoking in Middle and High School Students: A School-Based Cross-Sectional Study in Zhejiang Province, China." BMJ Open 6 (1): e010379. https://doi.org/10.1136/ bmjopen-2015-010379.

29. Warren, Charles W., Nathan R. Jones, Armando Peruga, James Chauvin, Jean-Pierre Baptiste, Vera Costa de Silva, Fatimah el Awa, et al. 2008. "Global Youth Tobacco Surveillance, 2000-2007." Morbidity and Mortality Weekly Report. Surveillance Summaries (Washington, D.C.: 2002) 57 (1): 1-28. 
30. Wong, David C. N., Sophia S. C. Chan, Sai-Yin Ho, Daniel Y. T. Fong, and Tai-Hing Lam. 2010. "Predictors of Intention to Quit Smoking in Hong Kong Secondary School Children.” Journal of Public Health (Oxford, England) 32 (3): 360-71. https://doi.org/10.1093/pubmed/fdp125.

31. World Health Organization. 2008. World Health Organization, Research for International Tobacco Control.
WHO Report on the Global Tobacco Epidemic, 2008: The MPOWER Package.

32. Xie, Bin, Paula Palmer, Yan Li, Cindy Lin, and C. Anderson Johnson. 2013. "Developmental Trajectories of Cigarette Use and Associations with Multilayered Risk Factors among Chinese Adolescents." Nicotine \& Tobacco Research: Official Journal of the Society for Research on Nicotine and Tobacco 15 (10): 1673-81. https://doi.org/10.1093/ntr/ntt035. 